\title{
Seabirds as indicators of food web structure and ecosystem variability: qualitative and quantitative diet analyses using fatty acids
}

\author{
Sara J. Iverson ${ }^{1, *}$, Alan M. Springer ${ }^{2}$, Alexander S. Kitaysky ${ }^{3}$ \\ ${ }^{1}$ Department of Biology, Dalhousie University, Halifax, Nova Scotia B3H 4J1, Canada \\ ${ }^{2}$ Institute of Marine Science, University of Alaska Fairbanks, Fairbanks, Alaska 99775-7220, USA \\ ${ }^{3}$ Institute of Arctic Biology, University of Alaska Fairbanks, Fairbanks, Alaska 99775-7000, USA
}

\begin{abstract}
The dynamics of predator-prey relationships, the structure of food webs, and the foraging behavior of individuals are critical to understanding animal ecology, interactions of predators with their prey, and effects of environmental variability on ecosystems. Like many other predators, seabirds are effective samplers of prey populations, and their diets can provide information about lower trophic levels over a range of spatial and temporal scales. Recognizing limitations of traditional methods of diet analysis, we validated the use of fatty acid (FA) signatures of subcutaneous adipose tissue biopsies for estimating diets of free-ranging seabirds. Calibration coefficients (CCs) for individual FAs were determined from captive common murres $(\mathrm{n}=13)$ fed a long-term, single-species diet. Quantitative FA signature analysis (QFASA), using these CCs, was then validated in murres $(\mathrm{n}=26)$ and red-legged kittiwakes $(n=13)$ fed controlled mixed-species diets. FAs were analyzed from 426 free-ranging red-legged Rissa brevirostris and black-legged kittiwakes $R$. tridactyla, and common Uria aalge and thick-billed murres $U$. lomvia from the Bering Sea, 284 of which were also sampled for stomach contents analysis. Qualitatively, FA signatures revealed distinct separation of diets among all 4 species, and further separation by location and year. QFASA diet estimates were similar to those based on stomach contents, with diets of kittiwakes dominated by myctophids, while those of murres comprised a mixture of other forage species. QFASA estimates were indicative of regional habitat differences, and were consistent with other aspects of seabird ecology at our study sites. We conclude that seabird FAs provide important information about ecosystems, but this will likely depend on each species' foraging behavior and the complexities of the ecosystem it occupies.
\end{abstract}

KEY WORDS: Seabirds · Fatty acids · Diet · Food webs · Black-legged kittiwakes Rissa tridactyla $\cdot$ Redlegged kittiwakes Rissa brevirostris · Common murres Uria aalge · Thick-billed murres Uria lomvia

\section{INTRODUCTION}

Describing complex interactions among species in ecosystems, how interactions are shaped by abiotic factors, and how they change over time and space can represent a tremendous challenge (Steele 1974). The concept of using information from upper trophic level predators to indicate ecosystem state, including information about lower trophic levels, has been acknowledged for several decades. For instance, species of marine mammals, as well as seabirds and predatory fish, have been used to indicate marine prey stocks and distribution, and to study habitats and food webs in relation to prey populations, oceanographic domains, and environmental variability (e.g. Springer et al 1984, 1986, 1996, Montevecchi 1993, Sinclair et al. 1994, Roseneau \& Byrd 1996, Boyd \& Murray 2001, Iverson et al. 2006). However, the nature and extent of what higher predator diets can tell us will likely depend on the foraging behavior of a given predator and the complexities of its ecosystem (e.g. McCafferty et al. 1999, Croxall 2006). 
If seabirds are to be useful as indicators and sentinels of marine ecosystem structure and variability, then we must find appropriate factors that are readily measured, sensitive to stresses or change, and are integrative. Among these, diet is an obvious choice. Studies of diets can provide information about food web differentiation and the importance and likely abundance of various prey across spatial and temporal scales. This information, in conjunction with other types of data, is important to understanding seabird distributions and population dynamics, and ecosystem structure and change over time.

Traditional approaches to studying seabird diets have well-known shortcomings and biases. For instance, analysis of stomach contents obtained from killed birds eliminates both the bird and the opportunity for longitudinal studies of individuals, and often, stomachs are empty. Additionally, information is obtained on only the most recent meal, which may not be reflective of longer-term diet, and prey with hard parts resistant to digestion, such as squid beaks, are overrepresented, while soft-bodied prey that are easily digested, such as euphausiids, are under-represented. Although stable isotopes can provide useful information (e.g. Hobson et al. 1994, Votier et al. 2003), they can generally only be used to estimate trophic level of feeding, not specific composition of diets. Visually identifying or intercepting prey carried in the beaks of adults when they return to the nest site to feed chicks (e.g. Hatch \& Sanger 1992), or identifying the contents of gular pouchs of auklets Aethia spp. (Bedard 1969), can be used only in some species and only during the relatively short annual period of chick rearing, and diets of chicks may differ significantly from those of adults (Furness et al. 1984, Hobson et al. 1994).

An alternative, or complementary, method for determining predator diets is to use fatty acid (FA) profiles, or signatures, in their adipose tissue (Iverson 1993). FAs are the largest constituent of lipids and their great diversity, biochemical restrictions, and, in some cases, unique origin among plants and animals has led to their use as trophic tracers in a wide variety of predators (reviewed in Budge et al. 2006). Alone, FA signatures can be used to examine differences or changes in foraging patterns or diets, both within and between populations of predator species, without specifying what species are eaten. However, used in conjunction with a detailed prey FA database and a recently developed statistical model, it is possible to quantitatively estimate the species composition of diets of individual predators at time scales relevant to the ecological processes affecting survival, as has been demonstrated in several marine and aquatic mammals (Iverson et al. 2004, 2006). Furthermore, adipose tissue samples for the analysis of FAs can be obtained from live predators by biopsy with minimal invasiveness. Although FA techniques have been used to infer foraging in a few seabird species (Raclot et al. 1998, Käkelä et al. 2005), to date, quantitative analysis has not been performed or validated. Therefore, our aim was to validate quantitative FA signature analysis (QFASA) as a method to estimate seabird diets, using both captive and field studies of 4 species in the Bering Sea, black-legged kittiwakes Rissa tridactyla (BLKI), red-legged kittiwakes $R$. brevirostris (RLKI), common murres Uria aalge (COMU), and thick-billed murres U. lomvia (TBMU).

\section{MATERIALS AND METHODS}

Sampling site and live biopsy technique. To first examine variability of FA composition within individuals, adipose tissue was sampled postmortem at 3 different locations in the body (mesenteric, breast, and subcutaneous at the synsacrum) in each of 18 birds, sacrificed in the wild, representing all 4 study species. The FA composition of all adipose tissue depots within individuals was indistinguishable (note: data available from the authors). Thus, since synsachral adipose tissue (on the lower back, anterior to the tail and avoiding the uropigial gland) can be obtained easily by biopsy from live birds, we sampled this adipose tissue depot in all remaining live and dead birds.

A live biopsy technique (Enderson \& Berger 1968) was used to obtain synsacral adipose tissue samples from captive birds and from live, free-ranging birds captured at nest sites. The bird was held cradled breast down, and ethanol (70\%) was swabbed on the feathers and skin covering the synsacrum to moisten the feathers and disinfect the area. The feathers were parted, and an incision of approximately $0.5 \mathrm{~cm}$ in length was made just through the skin. Between 0.05 and $0.30 \mathrm{~g}$ (depending on species and fat condition) of adipose tissue was excised using forceps and a scalpel blade, and placed in aluminum foil. The incision was then closed with surgical glue, and the bird was released. Samples were placed in chloroform containing $0.01 \%$ BHT (an antioxidant) in glass vials with Teflon-lined caps as soon as possible and stored frozen until analysis.

Captive feeding trials. Partially incubated eggs of COMU ( $\mathrm{n}=26$ ) and RLKI $(\mathrm{n}=13$ ) were collected in Cook Inlet and on the Pribilof Islands, Alaska, respectively, transported to captive facilities, and incubated until hatching (see Kitaysky et al. 2001, BenowitzFredericks \& Kitaysky 2005). Chicks were raised in individual nests and hand-fed controlled diets, half at $100 \%$ and half at 60 to $70 \%$ rations on each diet. COMU chicks were fed only silverside Menidia menidia from hatching until Day 10. From Days 11 to 45, half of the COMU chicks were continued only on sil- 
verside and the other half were fed only rainbow smelt Osmerus mordax. On Day 45, synsacral adipose tissue was obtained by biopsy from all individuals. RLKI chicks were fed a mixture of 8 parts herring Clupea harengus to 2 parts silverside from hatching until Day 15. From Days 16 to 42, half of the RLKI chicks were fed only silverside and the other half were fed only rainbow smelt, and all were biopsied on Day 42 . Biopsies were stored frozen in air-tight vials. Silverside ( $\mathrm{n}=15)$, rainbow smelt $(\mathrm{n}=15)$, and herring $(\mathrm{n}=10)$ were collected from the lots being fed, placed in airtight plastic bags, and stored frozen.

Field studies: free-ranging birds and prey. Synsacral adipose tissue samples were collected and analyzed from 426 free-ranging seabirds in 1999 and 2000 from St. Paul and St. George Islands (Pribilof Islands) and Bogoslof Island (Aleutian archipelago), Alaska: COMU ( $\mathrm{n}=68)$, TBMU ( $\mathrm{n}=136)$, RLKI $(\mathrm{n}=88)$, and BLKI $(\mathrm{n}=134)$. Birds were either captured alive ( $\mathrm{n}=$ 142), sampled by biopsy (as described above) and released, or sacrificed in the field $(\mathrm{n}=284)$ for other studies and used to compare diets derived from FAs with those from traditional stomach contents analyses. In the same years, a total of 161 individuals of 15 forage species believed to represent the potential prey was collected from the same areas as the birds-around the Pribilofs and Bogoslof-as opportunity provided, by ourselves, the National Marine Fisheries Service, and the U.S. Fish and Wildlife Service. Prey species collected included arrowtooth Atheresthes stomias and several other flounders Pleuronectidae spp., capelin Mallotus villosus, kelp greenling and other greenlings Hexagrammos spp., herring, walleye pollock Theragra chalcogramma, sandlance Ammodytes hexapterus, northern smooth-tongue Leuroglossus schmidti, myctophids (northern lampfish Stenobrachius leucopsarus), euphasiids Thysanoessa spp., and squids Gonatidae spp. All prey were placed in air-tight plastic bags and stored frozen until analysis.

Sample analyses. Lipid was quantitatively extracted from seabird fat samples and homogenates of each individual prey according to Iverson et al. (2001). FA methyl esters were prepared using acidic transesterification, analyzed in duplicate by gas chromatography using a polar capillary column coated with $50 \%$ cyanopropyl polysiloxane $(0.25 \mu \mathrm{m}$ film thickness; J\&W DB-23), and identified using a suite of techniques, according to all methods outlined in Iverson et al. $(1997,2002)$. Stomachs of all birds collected in the field were removed soon after death, and the contents were preserved frozen or in $70 \%$ ethanol until they were identified and enumerated. Prey remains were sorted and identified to the lowest taxonomic level practical, which was generally to species for fishes and to genera or families for invertebrates. Wet mass of prey was esti- mated using morphometric relationships between fish mass and otolith length and between squid mass and beak size, or by estimating lengths of prey lacking otoliths (e.g. fish without heads, other invertebrates) and using relationships relating estimated length to mass (e.g. Springer et al. 1996, Harvey et al. 2000).

Statistical analyses and QFASA. Differences among seabird species, location, and year were evaluated using a combination of univariate and multivariate techniques. Discriminant analysis (SPSS) was performed using the log-transformed percentage ratios of 17 FAs that had the largest overall variance and an overall mean of $\geq 0.4 \%$ of total FAs (Iverson et al. 2002). The diets of both captive and free-ranging birds were estimated using the QFASA model developed by Iverson et al. (2004) and the prey database we developed above, according to the 'Field Studies' section (see Iverson \& Springer 2002 for presentation of prey FA data). Basically, QFASA estimates the diet by weighting the mixture of FA signatures of prey species that most closely resemble that of the predator's adipose tissue stores and then after accounting for the relative fat content of each prey species, translates the signature mix into a diet estimate. An integral part of the QFASA model is the use of calibration coefficients (CCs) to account for predator lipid metabolism by weighting individual FAs according to their tissue deposition relative to diet (Iverson et al. 2004, 2006, Cooper et al. 2005). We calculated seabird CCs from the captive COMUs that had only been fed a constant diet of silverside since hatching.

\section{RESULTS}

\section{Captive validation studies}

The prey used in captive feeding trials differed somewhat in total lipid concentration, with herring averaging $5.2 \pm 0.28 \%$, silverside averaging $6.0 \pm$ $0.30 \%$, and rainbow smelt averaging $3.4 \pm 0.20 \%$ fat. However, the FA signatures of the 3 species differed markedly (Fig. 1a). For instance, of the 2 primary diet items, smelt was extremely high in 18:2n-6 and $18: 3 n-3$, components that are usually relatively rare in marine systems and thus low in free-ranging seabirds; in contrast to smelt, silverside was extremely high in 22:5n-3 and 22:6n-3. Both of the main diets (silverside and smelt) contained extremely low levels of the longchain monounsaturated isomers of 20:1 and 22:1 in contrast to herring. Consistent with large differences in the FA signatures of prey, there were large differences between the birds fed different diets (Fig. 1b). In large part, the FA signatures of COMU and RLKI fed similar diets (i.e. primarily silverside or primarily smelt) 


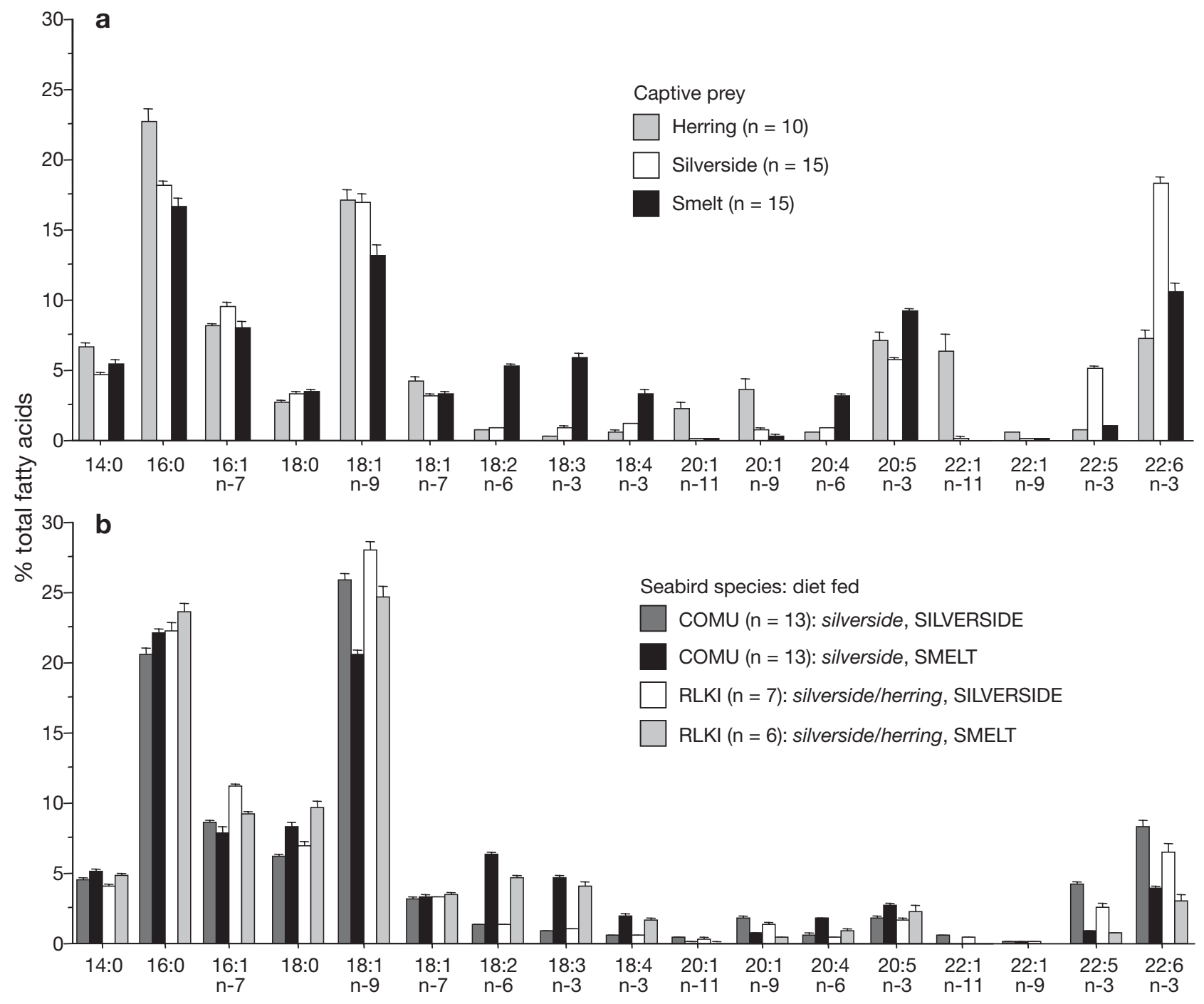

Fig. 1. Selected fatty acids (FAs; 17 of 67 identified) with the largest overall variance and an overall mean of $\geq 0.4 \%$ of total FAs and that illustrate characteristic differences in patterns: (a) among the 3 prey items fed to captive seabird chicks and (b) in the adipose tissue of common murres Uria aalge (COMU) and red-legged kittiwakes Rissa brevirostris (RLKI) chicks fed different diets (prey in italics fed from 0 to 10 or 15 d post-hatching, prey in capitals fed for the main period, from Day 10 or 15 until Day 42 or 45 ). Bars are means and vertical lines are $1 \mathrm{SE}$

closely resembled one another, especially in the longchain polyunsaturated FAs $(\geq 18: 2 n-6)$, while within each species, individuals fed different diets differed substantially. Absolute, although minor, differences in levels of FAs between COMU and RLKI fed the same predominant diet presumably reflected the fact that the 2 groups were fed different diets for the first 10 to $15 \mathrm{~d}$.

The 13 COMU chicks that were fed a constant diet of silverside from hatching until $45 \mathrm{~d}$ could be used to calculate CCs for individual FAs, since they were never fed anything else. In general, CCs were close to 1.0 for many of the FAs measured and, overall, were similar in nature to CCs previously calculated for phocid seals and mink Mustela vison fed marine diets (Fig. 2a: numerical values for CCs available from authors). Significant deviations were apparent in CCs for several FAs, especially several minor or trace components that are heavily influenced by biosynthesis. These and other FAs that arise solely from biosynthesis were not used in diet estimations. However, given the very tight response among individuals for almost all other FAs (in most cases SEs were too small to see), these CCs can be used to weight individual FAs in the QFASA model. These CCs were then applied to all captive birds in modeling diets. We ran the QFASA model using several different sets of FAs as outlined in Iverson et al. (2004), but since there were no significant differences in diet estimates by FA set, we used the 'extended dietary' set, which utilized the maximum number of 

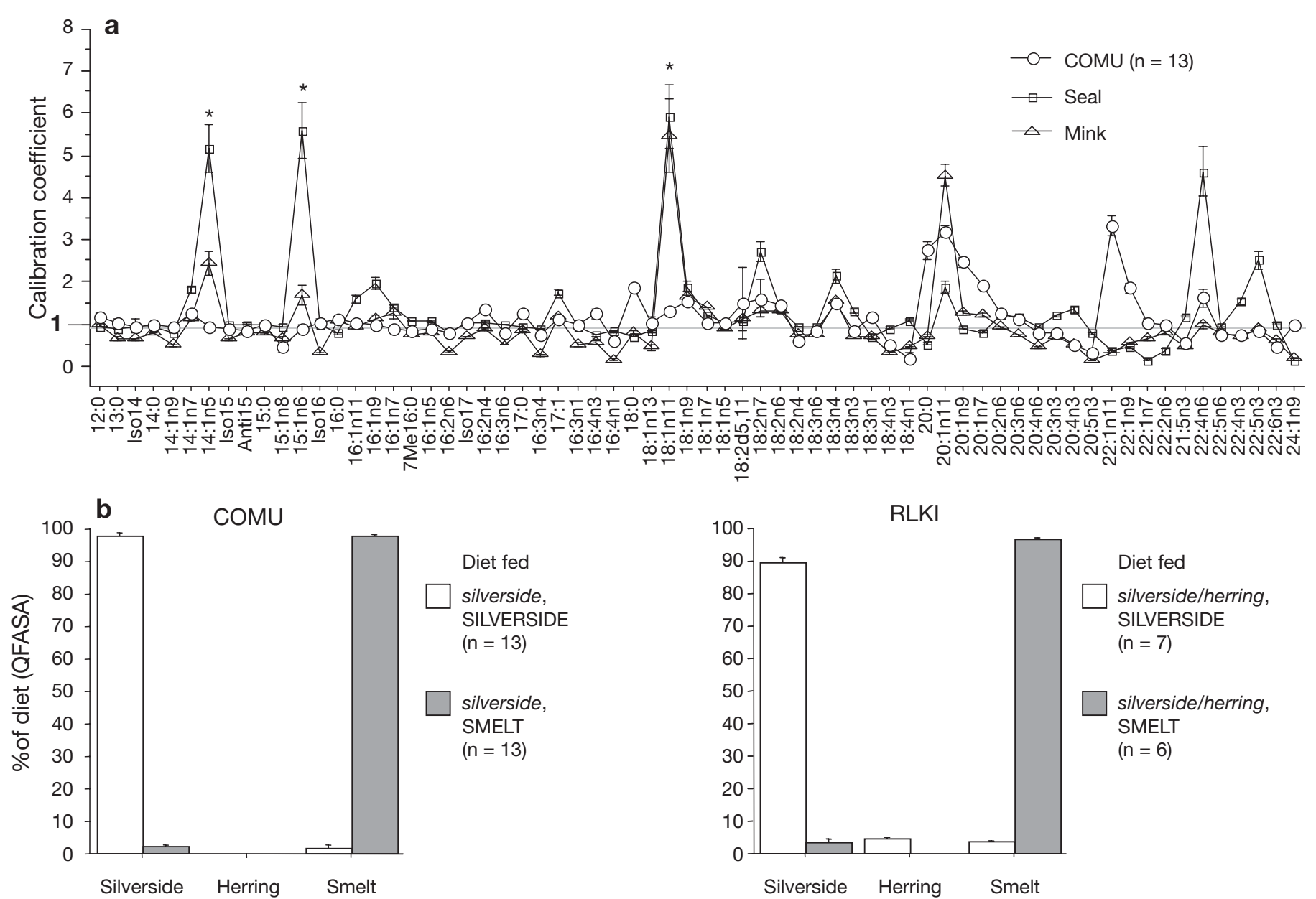

Fig. 2. (a) Seabird calibration coefficients (CCs) calculated from captive common murres (COMUs) fed a constant diet of silverside since hatching (means $\pm 1 \mathrm{SE}$ ). CCs calculated according to Iverson et al. (2004) as: \% of each FA in each bird/average \% of FAs in diet), but without trimmed means, as we did not use these in modeling diets of birds. Average CCs determined from previous studies of seals and mink (from Iverson et al. 2004) presented for comparison. The 1:1 line denotes deviation of a given FA in the predator from that consumed in diet. * = examples of FAs with large deviations from 1:1, but which occur at minor or trace amounts in marine lipids, with contributions from biosynthesis, and not used in quantitative fatty acid signature analysis (QFASA) modeling. (b) Estimated cumulative diets of captive COMU (at $45 \mathrm{~d}$ ) and red-legged kittiwakes (RLKI; at $42 \mathrm{~d}$ ) using the QFASA model and the COMU CCs from Panel a. Prey listed in italics were fed from 0 to 10 or $15 \mathrm{~d}$ post-hatching, and prey in capitals were fed for the main period, from Day 10 or 15 until Day 42 or 45. Bars are means of each species estimated in diets, and vertical lines are $1 \mathrm{SE}$

relevant FAs. QFASA estimates of diets of captive seabirds corresponded very well to the experimental diets (Fig. 2b). There was no significant difference between the groups fed $100 \%$ or 60 to $70 \%$ rations in the QFASA diet estimates (hence, apparent turnover of FAs); thus, both are averaged together. COMU fed only silverside were estimated to have only silverside in their diet, with no herring and only a trace of smelt incorrectly identified. In contrast, COMU fattened primarily on smelt were estimated to have fed primarily on smelt with some silverside, likely residual from the first $10 \mathrm{~d}$ of feeding; again no herring was detected. Likewise, the diets of RLKI estimated from QFASA corresponded to the known diets of primarily silverside or smelt, with some residual herring and silverside iden- tified from the first $15 \mathrm{~d}$ of feeding; a minor amount of smelt was misidentified in the silverside-fed birds.

\section{Free-ranging seabirds}

The FA composition of adipose tissue varied substantially across the 4 study species. Although differences were apparent in many of the minor components, differences among species were best illustrated by the most abundant and variable FAs (Fig. 3a). The largest differences, regardless of location or year sampled, were apparent between kittiwakes and murres. That is, FA patterns in COMU and TBMU were similar to one another and notably different from those observed 

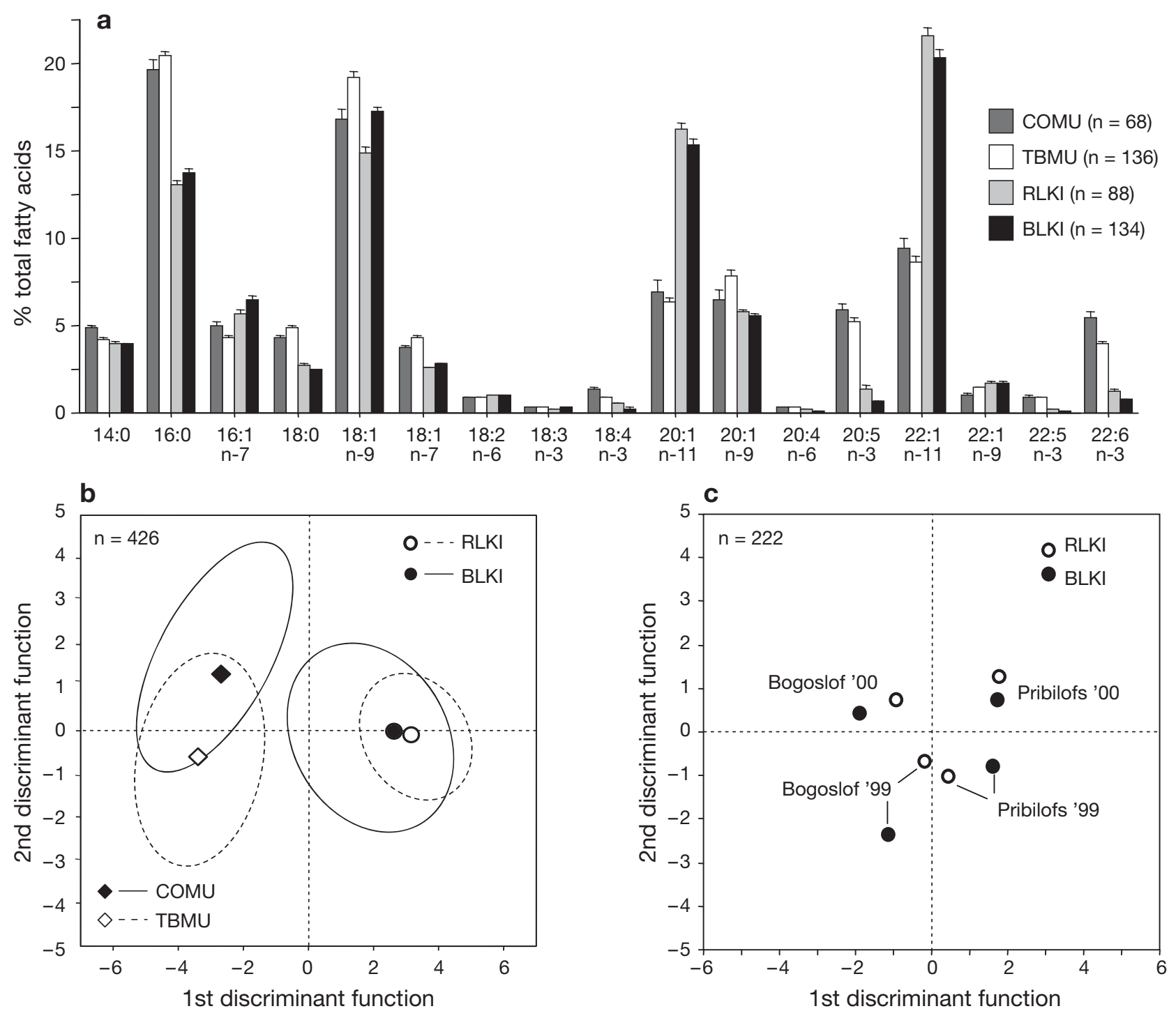

Fig. 3. (a) Selected FAs (17 of 67 identified) with the largest overall variance and an overall mean of $\geq 0.4 \%$ of total FAs that illustrate characteristic differences in patterns among free-ranging common and thick-billed murres (COMU and TBMU, respectively) and red-legged and black-legged kittiwakes (RLKI and BLKI, respectively). Bars are means, and vertical lines are 1 SE. FAs differed significantly among species ( $p<0.001$, MANOVA). (b) Plot of the group centroids (within-group mean for the first and second discriminant functions) from discriminant analysis performed on all individuals from (a). Ellipses represent $95 \%$ of the data point clouds for each species. The first 3 discriminant functions were significant $(p<0.001)$; the first function accounted for $98.5 \%$ of the variance: $71.7 \%$ of all original grouped cases and $68.8 \%$ of cross-validated grouped cases were correctly classified to species (Wilk's $\lambda<0.001$ ). Virtually all misclassifications were within the murres and kittiwakes, i.e. when separation of species groups (murres versus kittiwakes) was considered, individuals were accurately classified to species group with $>99 \%$ success. (c) Plot of the group centroids from discriminant analysis on RLKI $(n=88)$ and BLKI $(n=134)$ by major region and year. The first 5 discriminant functions were significant $(\mathrm{p}<0.001)$; the first 2 functions accounted for $74.2 \%$ of the variance: $68.1 \%$ of all original grouped cases and $61.7 \%$ of cross-validated grouped cases were correctly classified to species (Wilk's $\lambda<0.001$ ). Most misclassifications were within species, i.e. when all kittiwakes were grouped, individuals were accurately classified to major region and year with $83.4 \%$ success

in BLKI and RLKI. For instance, among FAs that arise solely or mostly from diet, kittiwakes had extremely high levels of 20:1n-11 and 22:1n-11 and very low levels of 18:4n-3, 20:5n-3, 22:5n-3, and 22:6n-3 in comparison to murres. Nevertheless, FA signatures also varied among individual species and differed considerably from those of the birds fed captive diets (Figs. 1b \& 3a). Results of discriminant analyses confirmed the significance of these overall species differences (Fig. 3b), but also demonstrated the broad overlap in FA signatures (and thus diet) of COMU with TBMU and of RLKI with BLKI. 
In addition to large overall differences between species, there was also significant within-species variability. For instance, there was clear evidence of differences by location and year in both kittiwakes and murres. When each species was considered separately, 96, 80 , and $80 \%$ of RLKI, BLKI, and TBMU, respectively, were correctly classified by location and year (small group sample size prevented this analysis for COMU). Considering RLKI and BLKI together, a plot of the group centroids illustrates annual and geographical differences in FA signatures between 1999 and 2000 at both Bogoslof and the Pribilofs, indicating differences in diets (Fig. 3c).

Of the 284 birds that were sacrificed, 49 had empty stomachs. The remaining 235 birds were used to qualitatively compare diet estimates from QFASA modeling of adipose tissue FAs and from prey remains in stom- achs. The QFASA and stomach contents analyses produced similar diet estimates within each of the 4 species (Fig. 4a, b). The principal difference was that QFASA indicated a greater proportion of some prey that occurred infrequently in stomachs and a lower proportion of squids. Both methods estimated that the diets of the 2 kittiwakes were dominated by myctophids, which appeared in only trace amounts in the murres. Although RLKI had the least diverse diet using either method, feeding primarily on myctophids, QFASA revealed that capelin, sand lance, and euphausiids each contributed about $10 \%$ to their diets. In contrast, murre diets were generally more diverse, composed primarily of fishes, such as capelin, pollock, sandlance, and northern smooth-tongue, and euphausiids. Squids, which were estimated to be of some importance to TBMU based on stomach contents

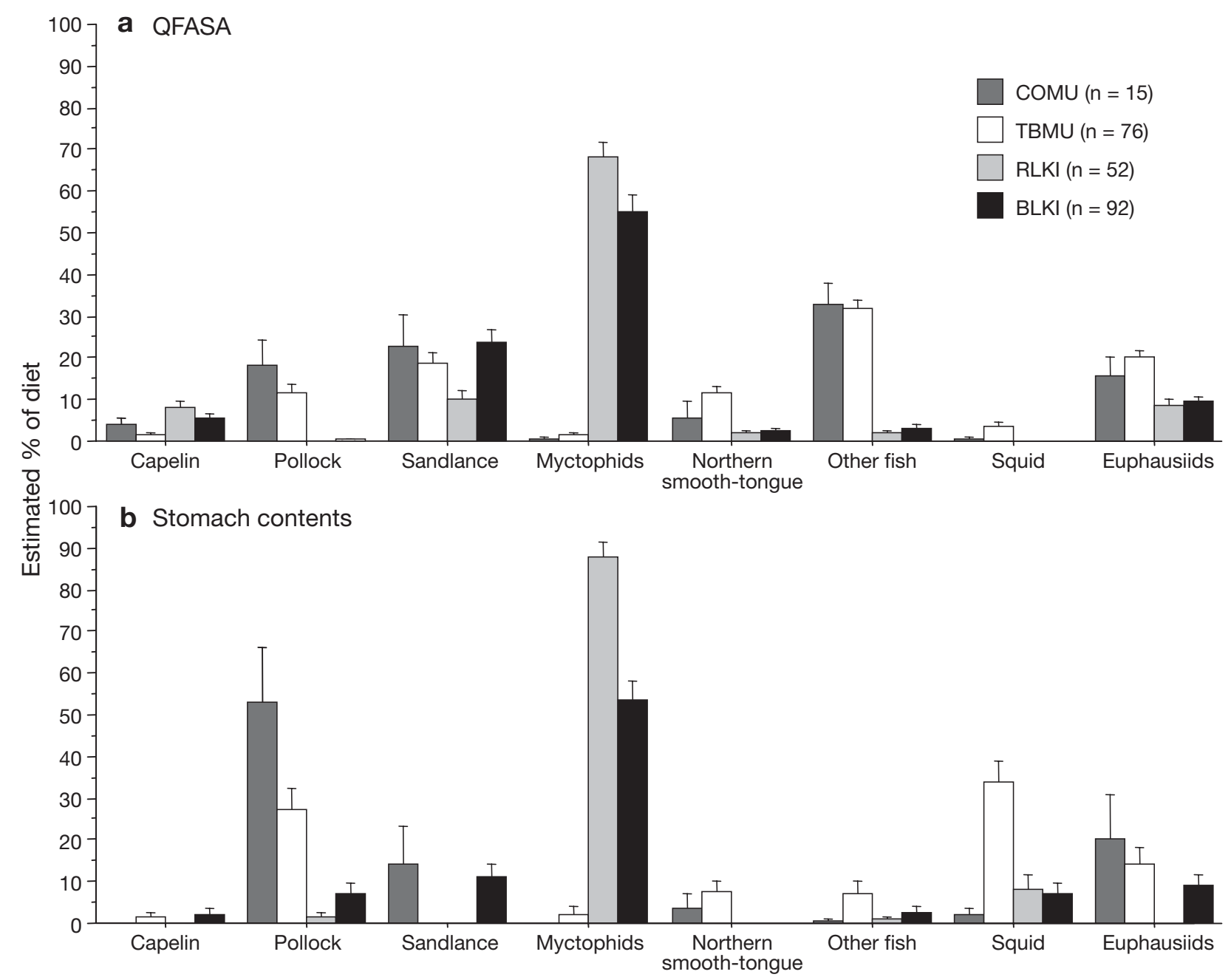

Fig. 4. (a) QFASA estimates of diets of free-ranging murres and kittiwakes ( $\mathrm{n}=235$ ) in comparison to (b) diet estimates from stomach contents analysis in the same individuals. Prey species present in the database, but not detected in diets by either method are not illustrated. 'Other fish' were identified in stomach contents merely as other fish. Using QFASA, these were individually identified and included species such as arrowtooth flounder, other flatfish, and greenlings, but are combined for presentation in order to compare with stomachs. Bars are means of each species estimated in diets, and vertical lines are 1 SE. For abbreviations see Fig. 3 
analyses, were found to be much less important when estimated by QFASA, and of little or no importance to COMU or kittiwakes.

QFASA results from the complete set of 426 birds were consistent with qualitative analyses of foraging (e.g. Fig. 3b,c) and revealed significant differences in diets with location (e.g. between the Pribilofs and Bogoslof overall, but also between St. Paul and St. George Islands) and with year in all 4 species $(\mathrm{p}<0.05$, MANOVA). Information obtained from QFASA could also be used to calculate average fat (and thus a proxy of energy) content of diets. On average, the fat contents of RLKI and BLKI diets $(11.9 \pm 0.22 \%$ and $10.2 \pm 0.32 \%$, respectively) were almost double those of COMU and TBMU diets $(4.8 \pm 0.19 \%$ and $5.9 \pm$ $0.15 \%$, respectively) $(\mathrm{p}<0.001)$. RLKI diets across both major regions were higher in fat content in 2000 (12.3 \pm $0.20 \%)$ than in $1999(10.3 \pm 0.50 \%)(\mathrm{p}<0.001)$, and were consistent with higher indices of productivity, e.g. clutch size, laying success, hatching success, fledging success, and chick growth (V. Byrd \& D. Kildaw unpubl. data) and lower levels of circulating corticosterone, an index of stress, in 2000 compared to 1999 (A. Kitaysky unpubl. data). However, it is not known whether this was related to dietary energy content or absolute intake of prey, as BLKI exhibited similar patterns in productivity, but diets did not differ significantly in fat content between the 2 yr. Fat content of murre diets varied only by about $10 \%$ between years, and murres exhibited no differences in productivity.

\section{DISCUSSION}

The results from our captive feeding studies clearly demonstrated that the greatest influence on the FA composition of adipose tissue is diet (Fig. 1). Hence, FAs can be used to qualitatively infer foraging and diet differences in free-ranging seabirds, among individuals, populations, and species, as well as over temporal and spatial scales. Patterns of adipose tissue FAs alone allowed us to discriminate diet differences between all 4 seabird species (black-legged kittiwakes Rissa tridactyla, red-legged kittiwakes $R$. brevirostris, common murres Uria aalge, and thick-billed murres U. lomvia), between the $2 \mathrm{yr}$, and between the Pribilofs and Bogoslof (e.g. Fig. 3). Differences we detected among species were consistent with results of other studies of murres and kittiwakes, which have shown varying degrees of dietary distinction among them in the Bering Sea (Hunt et al. 1981, Springer et al. 1996). The interannual differences we detected were also associated with differences between 1999 and 2000 in productivity and physiological condition of adults. Geographic variability in diets likely reflected food web structure that is, in turn, related to habitat characteristics across the region: Bogoslof is the most oceanic of the islands, lying in deep water just off the Aleutian Arc, whereas the Pribilofs lie in shallow water in the middle domain of the continental shelf, but near the ecotone between shelf and basin habitats. Species assemblages, including potential prey, in the basin are much different than on the shelf (Mecklenburg et al. 2002).

The results from the captive feeding studies further demonstrated that the response of adipose tissue FAs in seabirds to dietary FA intake is highly predictable (Fig. 2a) and that diet can be quantitatively and quite accurately characterized using QFASA in a simple system of 3 prey types (Fig. 2b). We then used the QFASA model to estimate diets of free-ranging seabirds in the Bering Sea using a much more complex prey database and compared these estimates to those derived from stomach contents in the same individuals. We would not expect results from the 2 analyses to be identical, as they are associated with different time scales of inference and the biases inherent in stomach content analyses preclude using them as a standard. Thus, we did not statistically test their similarity, but rather used the comparison as a framework for interpretation of QFASA. Both methods estimated the same dominant prey (Fig. 4a, b) and characterized well-established differences in typical diets of murres and kittiwakes across this region (e.g. Springer et al. 1996).

Differences between results of the QFASA and stomach contents analyses were consistent with expectations. For example, QFASA indicated a greater contribution of soft-bodied prey recorded infrequently in stomach contents and a lesser contribution of squids (the beaks of which are known to be selectively retained in stomachs). Likewise, QFASA estimated less pollock (relatively robust otoliths) and more capelin and sand lance (relatively small otoliths) than stomach contents did. QFASA was also able to quantify softbodied invertebrates, which were identified in stomachs in the present study, but commonly disintegrate quickly after being consumed (Furness et al. 1984, Hobson et al. 1994). Differences also likely arise from the fact that stomach contents generally represent diet consumed during the most recent feeding bout, whereas QFASA represents diets integrated over weeks.

We have demonstrated that QFASA can be a powerful technique for determining diets of free-ranging seabirds, providing opportunities for obtaining greater information than possible using other methods. Moreover, investigating such trophic relationships with traditional methods of diet analysis would require sacrificing great numbers of birds over an extended period each summer at each location. Many of the issues required for using QFASA and assembling a prey FA 
database have previously been reviewed (Iverson et al. 2004, Budge et al. 2006). Nevertheless, there remain several areas for further investigation with seabirds. The estimation of predator CCs is an integral component of QFASA. In our captive study, we assumed that after a long-term, single-species diet (in fact the only diet ever consumed), a bird's FA signature would look as much like the diet as it ever would, and used this as a basis for weighting FAs. Although there was a high degree of correspondence between seabirds and seal and mink data sets (Fig. 2a), and we are confident we have good estimates of the CCs for the seabirds used in our experiment given the success of our QFASA modeling, clearly more studies are needed to confirm patterns of FA deposition with additional species and with adults versus chicks. For instance, while variation was clearly apparent, the only important dietary FA with a $\mathrm{CC}$ in birds quite different than that of both seals and mink, on average, was 22:1n-11, which was also quite low in the silverside fed to the CC birds (Fig. 1a). Thus, it would be useful to evaluate this in future studies. Interestingly, unlike previous studies, the choice of the FA set used for modeling, including removal of FAs with large CCs, had no significant effect on diet estimates. In addition to the above issues, a better understanding of the time scales over which changes in diet are reflected, and the effects of ration size are also important.

QFASA estimates of diet meet several important requirements for ecological indicators: FA are easily measured, sensitive to change and responsive to change in a predictable manner, and are integrative. A particular advantage of QFASA is that fat samples can be obtained humanely, with minimal invasiveness, allowing greater sample sizes as well as longitudinal studies of individuals. Coupled with information on the physiological status of individuals and on the outcome of individual and colony-wide nesting attempts, we have tools that will help us to greatly improve our understanding of the nature and consequences of fluctuations in food web productivity critical to the maintenance of seabird populations. Such detailed information will be especially useful in furthering our understanding of how ecosystems vary spatially and temporally in response to climate change and other perturbations.

Acknowledgements. All procedures were conducted under guidelines of the Institutional Animal Care and Use Committees (IACUC) at University of Washington and University of Alaska Fairbanks. We are indebted to V. Byrd, A. Sowls, and others at the Alaska Maritime National Wildlife Refuge (US Fish and Wildlife Service) for their support and collaboration in our work; Captain K. Bell and the crew of the M/V 'Tiglax', for their skill in safely deploying personnel to Bogoslof Island; and the National Marine Fisheries Service for providing for- age species from the Bering Sea. We thank W. D. Bowen and 3 anonymous reviewers for very helpful comments on an earlier version of the manuscript. Financial support was provided by the North Pacific Marine Research (NPMR) program and the North Pacific Research Board (NPRB) to the project 'Regime Forcing and Ecosystem Response (ReFER)'. Additional support was provided by the U.S. Fish and Wildlife Service, U.S. Geological Survey, and by the Natural Sciences and Engineering Council (NSERC) Canada. This is NPRB Publication Number 80.

\section{LITERATURE CITED}

Bedard J (1969) Feeding of the least, crested and parakeet auklets on St. Lawrence Island, Alaska. Can J Zool 47:1025-1050

Benowitz-Fredericks ZM, Kitaysky AS (2005) Benefits and costs of rapid growth in common murre (Uria aalge) chicks. J Avian Biol 36:287-294

Boyd IL, Murray AWA (2001) Monitoring a marine ecosystem using responses of upper trophic level predators. J Anim Ecol 70:747-760

Budge SM, Iverson SJ, Koopman HN (2006) Studying trophic ecology in marine ecosystems using fatty acids: a primer on analysis and interpretation. Mar Mamm Sci 22:759-801

Cooper MH, Iverson SJ, Heras H (2005) Dynamics of blood chylomicron fatty acids in a marine carnivore: implications for lipid metabolism and quantitative estimation of predator diets. J Comp Physiol B 175:133-145

Croxall JP (2006) Monitoring preditor-prey interactions using multiple predator species: the South Georgia experience. In: Boyd IL, Wanless, S, Camphuysen CJ (eds) Top predators in marine ecosystems: their role in monitoring and management. Cambridge University Press, Cambridge, p 157-176

Enderson JH, Berger DD (1968) Chlorinated hydrocarbon residues in peregrines and their prey species from northern Canada. Condor 70:149-153

Furness BL, Laugksch RC, Duffy DC (1984) Cephalopod beaks and studies of seabird diets. Auk 101:619-620

Harvey JT, Loughlin TR, Perez MA, Oxman DS (2000) Relationship between fish size and otolith length for 63 species of fishes from the eastern North Pacific Ocean. NOAA Tech Rep 150

Hatch SA, Sanger GA (1992) Puffins as samplers of juvenile pollock and other forage fish in the Gulf of Alaska. Mar Ecol Prog Ser 80:1-14

Hobson KA, Piatt JF, Pitocchelli J (1994) Using stable isotopes to determine seabird trophic relationships. J Anim Ecol 63:786-798

Hunt GL Jr, Burgesson B, Sanger GA (1981) Feeding ecology of seabirds of the eastern Bering Sea. In: Hood DW, Calder JA (eds) The eastern Bering Sea shelf: oceanography and resources, Vol. 2. NOAA, Juneau, AK, p 629-648

Iverson SJ (1993) Milk secretion in marine mammals in relation to foraging: Can milk fatty acids predict diet? Symp Zool Soc Lond 66:263-291

Iverson SJ, Springer AM (2002) Estimating seabird diets using fatty acids: protocol development and testing of ReFER hypotheses. Report to the National Pacific Marine Research Program, University of Alaska, Fairbanks, AK

Iverson SJ, Frost KJ, Lowry LL (1997) Fatty acid signatures reveal fine scale structure of foraging distribution of harbor seals and their prey in Prince William Sound, Alaska. Mar Ecol Prog Ser 151:255-271

Iverson SJ, Lang SLC, Cooper MH (2001) Comparison of the 
Bligh and Dyer and Folch methods for total lipid determination in a broad range of marine tissue. Lipids 36 : 1283-1287

Iverson SJ, Frost KJ, Lang SLC (2002) Fat content and fatty acid composition of forage fish and invertebrates in Prince William Sound, Alaska: factors contributing to among and within species variability. Mar Ecol Prog Ser 241:161-181

Iverson SJ, Field C, Bowen WD, Blanchard W (2004) Quantitative fatty acid signature analysis: a new method of estimating predator diets. Ecol Monogr 74:211-235

Iverson SJ, Stirling I, Lang SLC (2006) Spatial and temporal variation in the diets of polar bears across the Canadian arctic: indicators of changes in prey populations and environment. In: Boyd IL, Wanless S, Camphuysen CJ (eds) Top predators in marine ecosystems: their role in monitoring and management. Cambridge University Press, Cambridge, p 98-117

Käkelä R, Käkelä A, Kahle S, Becker PH, Kelly A, Furness RW (2005) Fatty acid signatures in plasma of captive herring gulls as indicators of demersal or pelagic fish diet. Mar Ecol Prog Ser 293:191-200

Kitaysky AS, Kitaiskaia EV, Wingfield JC, Piatt JF (2001) Dietary restriction causes chronic elevation of corticosterone and enhances stress response in red-legged kittiwake chicks. J Comp Physiol B 171:701-709

McCafferty DJ, Boyd IL, Walker TR, Taylor RI (1999) Can marine mammals be used to monitor oceanographic conditions? Mar Biol 134:387-395

Mecklenburg CW, Mecklenburg TA, Thorsteinson LK (2002) Fishes of Alaska. American Fisheries Society, Bethesda, MD

Montevecchi WA (1993) Birds as indicators of change in prey

Editorial responsibility: Howard Browman (Associate Editorin-Chief), Storebø, Norway stocks. In: Furness RW, Greenwood JJD (eds) Birds as monitors of environmental change. Chapman \& Hall, London, p 217-266

Raclot T, Groscolas R, Cherel Y (1998) Fatty acid evidence for the importance of myctophid fishes in the diet of king penguins, Aptenodytes patagonicus. Mar Biol 132: 523-533

Roseneau DG, Byrd GV (1997) Using Pacific halibut to sample the availability of forage fishes to seabirds. In: Forage fishes in marine ecosystems. Proceedings of the international symposium on the role of forage fishes in marine ecosystems. University of Alaska, Fairbanks, AK, p 231-241

Sinclair E, Loughlin T, Pearcy W (1994) Prey selection by northern fur seals (Callorhinus ursinus) in the eastern Bering Sea. Fish Bull (Wash DC) 92:144-156

Springer AM, Roseneau DG, Murphy EC, Springer MI (1984) Environmental controls of marine food webs: food habits of seabirds in the eastern Chukchi Sea. Can J Fish Aquat Sci 41:1202-1215

Springer AM, Roseneau DG, Lloyd DS, McRoy CP, Murphy EC (1986) Seabird responses to fluctuating prey abundance in the eastern Bering Sea. Mar Ecol Prog Ser 32: $1-12$

Springer AM, Piatt JF, van Vliet G (1996) Sea birds as proxies of marine habitats and food webs in the western Aleutian Arc. Fish Oceanogr 5: 45-55

Steele JH (1974) The structure of marine ecosystems. Harvard University Press, Cambridge, MA

Votier SC, Bearhop S, MacCormick A, Ratcliffe N, Furness RW (2003) Assessing the diet of great skuas, Catharacta skua, using five different techniques. Polar Biol 26:20-26

Submitted: September 28, 2006; Accepted: July 27, 2007 Proofs received from author(s): October 7, 2007 